\title{
Bacillus shackletonii sp. nov., from volcanic soil on Candlemas Island, South Sandwich archipelago
}

\author{
Correspondence \\ Niall A. Logan \\ N.A.Logan@gcal.ac.uk
}

\author{
Niall A. Logan, ${ }^{1}$ Liesbeth Lebbe, ${ }^{2}$ An Verhelst, ${ }^{2}$ Johan Goris, ${ }^{2}$ \\ Gillian Forsyth, ${ }^{1}$ Marina Rodríguez-Díaz, ${ }^{1}$ Marc Heyndrickx ${ }^{2} \dagger$ \\ and Paul De Vos ${ }^{2}$
${ }^{1}$ School of Biological and Biomedical Sciences, Glasgow Caledonian University, Cowcaddens Road, Glasgow G4 OBA, UK
${ }^{2}$ Vakgroep BFM WE10V, Laboratorium voor Microbiologie, Universiteit Gent, K. L. Ledeganckstraat 35, B-9000 Gent, Belgium

\begin{abstract}
A sample of mossy soil taken from the eastern lava flow of northern Candlemas Island, South Sandwich archipelago, yielded six isolates of aerobic, endospore-forming bacteria. Miniaturized routine phenotypic tests and other observations, amplified rDNA restriction analysis and SDS-PAGE analysis suggested that the strains represent a novel taxon. 16S rDNA sequence comparisons support the proposal of a novel species, Bacillus shackletonii sp. nov., the type strain of which is LMG $18435^{\top}\left(=\right.$ CIP $\left.107762^{\top}\right)$.
\end{abstract}

Logan et al. (2000) reported the isolation of aerobic, endospore-forming bacteria from six soil samples collected during the 1996-1997 austral summer from different parts of northern Candlemas Island in the South Sandwich archipelago (see figures and plates in Tomblin, 1979; Fig. 1 in Logan et al., 2000). The northern part of Candlemas Island is actively volcanic and comprises a roughly circular mass of five main lava flows surrounding Lucifer Hill, which is a complex of scoria cones with active fumaroles. The east flow is one of the oldest and bears an ash mantle, while the youngest, north, lava field is very recent (Tomblin, 1979). Samples of mossy soil, whose temperatures ranged from $85{ }^{\circ} \mathrm{C}$ at the summit of the hill to $0{ }^{\circ} \mathrm{C}$ at its base, were collected by British Antarctic Survey personnel for the purpose of investigating the aerobic, endospore-forming bacterial flora. It was found that two strains (LMG $18422^{\mathrm{T}}$ and LMG $18435^{\mathrm{T}}$ ) represented unidentifiable species of Bacillus, while other samples yielded unidentified members of Paenibacillus. Further isolations from the soil sample that yielded LMG $18422^{\mathrm{T}}$ led to the proposal of the novel species Bacillus luciferensis (Logan et al., 2002). The present note describes the isolation and characterization of LMG $18435^{\mathrm{T}}$ and five other isolates found in a sample of unheated soil taken from the east lava flow, and proposes the novel species Bacillus shackletonii sp. nov.

\section{†Present address: Government Dairy Research Station,} Brusselsesteenweg 370, B-9090 Melle, Belgium.

The EMBL accession number for the 16S rRNA gene sequence of Bacillus shackletonii LMG $18435^{\top}$ is AJ250318.

Details of the fatty acid methyl ester compositions of $B$. shackletonii strains are available as supplementary data in IJSEM Online.
Strains were isolated from trypticase soy broth enrichments at pH $5 \cdot 5$ incubated at $40^{\circ} \mathrm{C}$, but were subsequently cultivated and maintained on trypticase soy agar at $\mathrm{pH} 6 \cdot 5$, containing $5 \mathrm{mg} \mathrm{MnSO}_{4} \mathrm{l}^{-1}$ to enhance sporulation, with incubation at $30^{\circ} \mathrm{C}$ as described by Logan et al. (2000). Strain LMG $18435^{\mathrm{T}}\left(=\mathrm{B} 1724^{\mathrm{T}}\right)$ and the further strains R11667, R-11668, R-14112, R-14113 and R-14114 (=B1725, $\mathrm{B} 1726, \mathrm{~B} 1843, \mathrm{~B} 1844$ and $\mathrm{B} 1845$, respectively) were isolated from a sample of unheated mossy soil collected at the north-western margin of the east lava flow near the foot of Lucifer Hill (temperature range $0-15{ }^{\circ} \mathrm{C}$; altitude $30 \mathrm{~m}$; site 6 in Logan et al., 2000); this flow forms a plain, known as Breakbones Plateau, that is covered by a mantle of stratified ash (Holdgate \& Baker, 1979; Tomblin, 1979). Strains were phenotypically characterized as described by Logan \& Berkeley (1984) and Logan et al. (2000); anaerobic growth was tested using a GasPak jar (Becton Dickinson) with a methylene blue indicator strip, and an aerobic control culture. All six strains were subjected to GC analysis of methylated fatty acids, SDS-PAGE analysis, amplified rDNA restriction analysis and DNA base composition analysis; strain LMG $18435^{\mathrm{T}}$ was also subjected to $16 \mathrm{~S}$ rDNA sequencing, as described by Logan et al. (2000, 2002). The $\mathrm{G}+\mathrm{C}$ content of the DNA was determined by HPLC (Mesbah et al., 1989) using further specifications given by Logan et al. (2000). Antibiotic sensitivities were measured using Mastrings (MAST Laboratories) on IsoSensitest agar (Oxoid).

All of the strains were found to be Gram-negative, aerobic, motile rods that formed ellipsoidal spores lying subterminally, and sometimes paracentrally, in sporangia that were usually slightly swollen (Fig. 1). The strains gave similar patterns of results in the phenotypic analyses, although 


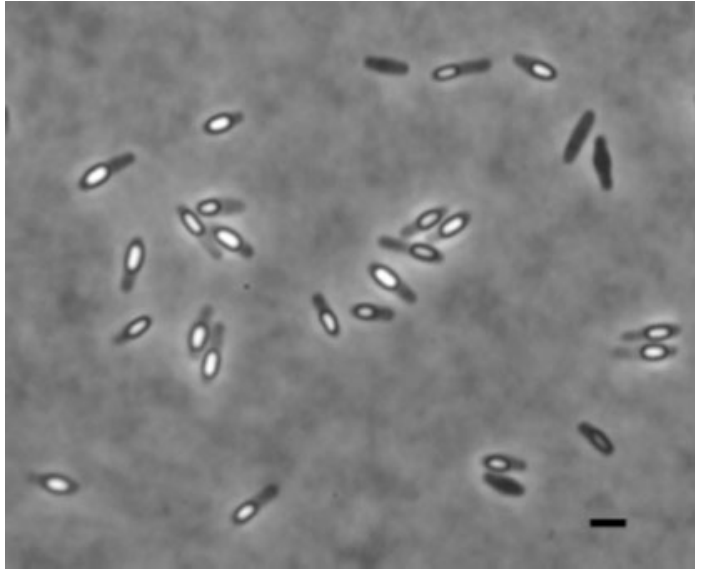

Fig. 1. Photomicrograph of sporangia and vegetative cells of the type strain of $B$. shackletonii sp. nov. viewed by phasecontrast microscopy; ellipsoidal spores lie subterminally, and occasionally paracentrally, in sporangia that are usually swollen. Bar, $2 \mu \mathrm{m}$

many reactions were weak, and they clustered together at $95 \%$ similarity in a UPGMA cluster analysis (not shown) based upon these characteristics; this cluster merged with strains of Bacillus firmus at only $85 \%$ similarity and with strains of B. luciferensis, Bacillus oleronius and Bacillus sporothermodurans at $82.5 \%$ similarity, indicating that the novel strains form a group that is phenotypically distinct. The characteristics that differentiate this group of strains from phenotypically similar species are shown in Table 1. Although the six strains were isolated from the same sample of soil, they showed sufficient phenotypic variation to suggest that they are not merely repeated isolations of the same strain. Comparison of the amplified rDNA restriction analysis pattern of strain LMG $18435^{\mathrm{T}}$ with a database of over 1000 authentic strains of species of aerobic endosporeforming bacteria did not yield a clear-cut identification; the highest similarities were only $84 \%$ to the type strain of Bacillus smithii and $82 \%$ to the type strain of $B$. sporothermodurans. The six strains subjected to SDS-PAGE analysis showed at least $86 \%$ similarity, reflecting limited intraspecies variation (Fig. 2), which, given the high similarity between these strains in terms of the other phenotypic characteristics, remains consistent with the view that these strains belong to the same species (strain R-11668 is not included in Fig. 2 as it gave a weak pattern). The six strains also showed very similar profiles for major cellular
Table 1. Characteristics that distinguish between B. shackletonii sp. nov. and some phenotypically similar and phylogenetically related Bacillus species

Species: 1, B. shackletonii sp. nov.; 2, B. sporothermodurans; 3, B. oleronius; 4, B. luciferensis; 5, B. firmus; 6, B. cereus; 7, B. subtilis. With the exception of microscopic observations, anaerobic growth and casein hydrolysis, all characteristics were determined using tests in the API 20E and 50 CHB systems (bioMérieux). +, $>85 \%$ Positive; $(+), 75-84 \%$ positive; V, variable $(26-74 \%$ positive);,$- 0-15 \%$ positive; $\mathrm{W}$, weak positive reaction. All species are positive for aesculin hydrolysis.

\begin{tabular}{|c|c|c|c|c|c|c|c|}
\hline Characteristic & 1 & 2 & 3 & 4 & 5 & 6 & 7 \\
\hline \multicolumn{8}{|l|}{ Spore formation: } \\
\hline Spore position* & S (C) & $\mathrm{T}$ & S, C & $\mathrm{S}(\mathrm{T})$ & S, C & S (C) & $\mathrm{s}$ \\
\hline Sporangia swollen & + & - & + & $\mathrm{V}$ & - & - & - \\
\hline Anaerobic growth & - & - & - & + & + & + & - \\
\hline Gelatin hydrolysis & $-\dagger$ & - & - & + & + & + & + \\
\hline Casein hydrolysis & $\mathrm{W} \ddagger$ & - & - & + & + & + & + \\
\hline Nitrate reduction & - & - & + & - & $(+)$ & $\mathrm{V}$ & + \\
\hline Voges-Proskauer reaction & $-\dagger$ & $\mathrm{w}$ & $\mathrm{V}$ & + & + & + & + \\
\hline \multicolumn{8}{|l|}{ Acid from: } \\
\hline Amygdalin & + & - & - & + & - & - & + \\
\hline Galactose & $\mathrm{w}$ & - & - & - & - & - & $\mathrm{V}$ \\
\hline$\beta$-Gentiobiose & $\mathrm{W}$ & - & - & + & - & - & + \\
\hline Glycerol & - & - & V & - & + & + & + \\
\hline Lactose & $\mathrm{w}$ & - & - & - & - & - & $\mathrm{V}$ \\
\hline D-Mannose & $\mathrm{W}$ & - & V & - & $(+)$ & - & + \\
\hline D-Melezitose & - & - & - & + & - & - & - \\
\hline Ribose & $\mathrm{w}$ & - & + & - & $\mathrm{V}$ & + & + \\
\hline Salicin & + & $\mathrm{W}$ & $\mathrm{V}$ & + & - & + & + \\
\hline Starch & - & - & + & $\mathrm{W}$ & + & + & + \\
\hline Sucrose & - & + & $\mathrm{V}$ & + & + & $\mathrm{V}$ & + \\
\hline D-Tagatose & $\mathrm{W}$ & + & + & - & - & - & - \\
\hline
\end{tabular}

${ }^{\star} \mathrm{C}$, Central/paracentral; $\mathrm{S}$, subterminal; $\mathrm{T}$, terminal. Positions that are infrequently observed are shown in parentheses.

$\dagger$ Gelatin hydrolysis and Voges-Proskauer reactions may become positive slowly at $40{ }^{\circ} \mathrm{C}$.

$\ddagger$ Grows poorly and gives weak reactions, or does not grow at all, on casein agar.

fatty acids; these were dominated by anteiso $\mathrm{C}_{15: 0}$, iso $\mathrm{C}_{15: 0}$, iso $\mathrm{C}_{16: 0}$ and anteiso $\mathrm{C}_{17: 0}$ components, which respectively represented about $35,31,6$ and $18 \%$ of total fatty acids (details available as supplementary material in IJSEM Online). In $16 \mathrm{~S}$ rDNA sequence comparisons with

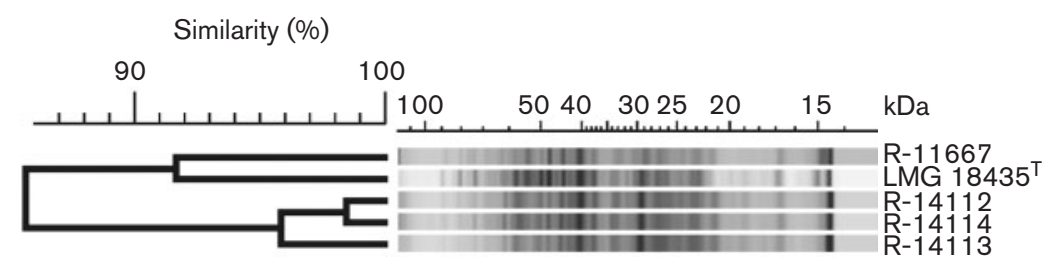

Fig. 2. Normalized computer profiles from SDS-PAGE analyses of whole-cell proteins of five $B$. shackletonii strains. The dendrogram is based on UPGMA clustering of the correlation coefficient $(r)$ of the total protein profiles. The zone used for clustering was between point 50 and point 340 (a complete lane contains 400 points). 


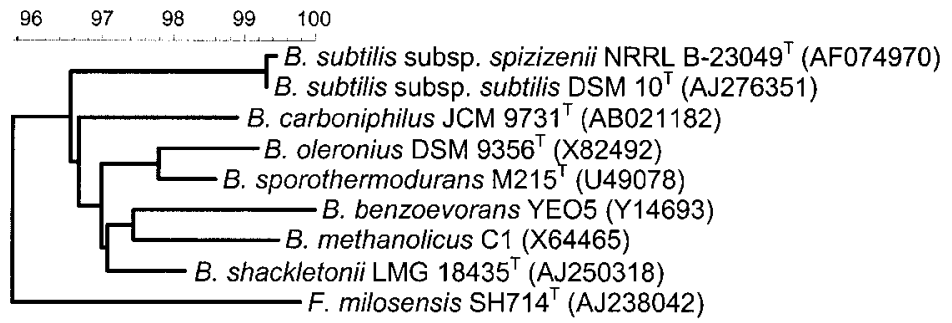

Fig. 3. Neighbour-joining clustering of $16 \mathrm{~S}$ rDNA sequences (rooted with Filobacillus milosensis) based on a selection of $16 \mathrm{~S}$ rDNA sequences from the EMBL database (accession numbers are given) and $B$. shackletonii sp. nov. LMG $18435^{\top}$.

entries in the EMBL database, the closest matches achieved for LMG $18435^{\mathrm{T}}$ were with B. oleronius $(96 \cdot 6 \%$ similarity) and B. sporothermodurans (97.2\% similarity) (Fig. 3). Our failure to identify the Candlemas Island strains by means of the genotypic and phenotypic methods tried, and the strong phenotypic similarities among the strains, support the proposal of a novel species, Bacillus shackletonii sp. nov., with LMG $18435^{\mathrm{T}}$ as the type strain.

\section{Description of Bacillus shackletonii sp. nov.}

Bacillus shackletonii (sha.ckle.ton'i.i. N.L. gen. n. shackletonii of Shackleton, referring to RRS Shackleton, the ship used by the first British scientific expedition to visit Candlemas Island, the vessel being named in honour of the celebrated Anglo-Irish Antarctic explorer Sir Ernest Shackleton).

Isolated from unheated volcanic soil taken from the east lava flow of Candlemas Island, South Sandwich archipelago. Cells are motile, round-ended rods $(0 \cdot 7-0 \cdot 9 \times 2 \cdot 5-4 \cdot 5 \mu \mathrm{m})$ occurring singly. Gram-variable; Gram-positive reactions are only seen in cultures at $18 \mathrm{~h}$ or at temperatures below $30{ }^{\circ} \mathrm{C}$. Endospores are ellipsoidal, lie subterminally and occasionally paracentrally, and usually cause the sporangia to swell (Fig. 1). After 2 days on trypticase soy agar, colonies are $2-5 \mathrm{~mm}$ in diameter, have a granular appearance and butyrous texture, have opaque, cream-coloured centres and have translucent, irregular margins. The minimum temperature for growth lies between 15 and $20^{\circ} \mathrm{C}$, the optimum temperature for growth is $35-40{ }^{\circ} \mathrm{C}$ and the maximum growth temperature is $50-55^{\circ} \mathrm{C}$. The minimum $\mathrm{pH}$ for growth lies between $4 \cdot 5$ and $5 \cdot 0$, the optimum $\mathrm{pH}$ for growth is $7 \cdot 0$ and the maximum $\mathrm{pH}$ for growth lies between $8 \cdot 5$ and $9 \cdot 0$. Organisms are strictly aerobic and catalase-positive. They do not grow readily on casein agar but, when they do grow on it, they may hydrolyse the casein. Starch is not hydrolysed. In the API 20E strip (bioMérieux) incubated at $30^{\circ} \mathrm{C}$, ONPG is hydrolysed slowly; reactions for arginine dihydrolase, lysine decarboxylase, ornithine decarboxylase, citrate utilization, hydrogen sulphide production, urease, tryptophan deaminase, indole production, the Voges-Proskauer reaction, gelatin hydrolysis and nitrate reduction are negative (in the API $20 \mathrm{E}$ strip incubated at $40^{\circ} \mathrm{C}$, citrate may be utilized slowly, gelatin may be hydrolysed slowly and the VogesProskauer reaction may be positive). In the API $50 \mathrm{CH}$ gallery (bioMérieux), hydrolysis of aesculin is positive. Acid without gas is produced from the following carbohydrates in the API $50 \mathrm{CH}$ gallery using the $\mathrm{CHB}$ suspension medium (bioMérieux): amygdalin, cellobiose, D-glucose, $N$ acetylglucosamine and salicin; weak acid reactions were detected for arbutin, D-fructose, galactose, $\beta$-gentiobiose, lactose, maltose, $\mathrm{D}$-mannitol, $\mathrm{D}$-mannose, ribose, $\mathrm{D}$-tagatose and D-trehalose. Acid is not produced from the following carbohydrates: adonitol, D- and L-arabinose, D- and L-arabitol, dulcitol, erythritol, D- and L-fucose, gluconate, glycerol, glycogen, meso-inositol, inulin, 2-keto-D-gluconate, 5-keto-D-gluconate, D-lyxose, D-melezitose, melibiose, methyl $\alpha$-D-glucoside, methyl $\alpha$-D-mannoside, methyl xyloside, D-raffinose, rhamnose, sorbitol, L-sorbose, starch, sucrose, D-turanose, xylitol and D- and L-xylose. Cells are sensitive to filter-paper disks containing the following antibiotics: ampicillin $(25 \mu \mathrm{g})$, chloramphenicol $(50 \mu \mathrm{g})$, colistin sulphate $(100 \mu \mathrm{g})$, kanamycin $(30 \mu \mathrm{g})$, nalidixic acid $(30 \mu \mathrm{g})$, nitrofurantoin $(50 \mu \mathrm{g})$, streptomycin $(25 \mu \mathrm{g})$ and tetracycline $(100 \mu \mathrm{g})$. The major cellular fatty acids are anteiso $\mathrm{C}_{15: 0}$, iso $\mathrm{C}_{15: 0}$, iso $\mathrm{C}_{16: 0}$ and anteiso $\mathrm{C}_{17: 0}$ (respectively representing about $35,31,6$ and $18 \%$ of total fatty acids). The following fatty acids were present in smaller amounts (between about 1 and $3 \%$ ): $\mathrm{C}_{14: 0}$, iso $\mathrm{C}_{14: 0}$, iso $\mathrm{C}_{16: 1 \omega 11 c}$, summed feature $4\left(\mathrm{C}_{17: 1}\right.$ iso $\mathrm{I}$ and/or $\mathrm{C}_{17: 1}$ anteiso B) and iso $\mathrm{C}_{17: 1 \omega 10 c}$. Details of the fatty acid methyl ester composition are available as supplementary data in IJSEM Online. The $\mathrm{G}+\mathrm{C}$ content of the DNA varies between $35 \cdot 4 \mathrm{~mol} \%$ (type strain) and $36 \cdot 8 \mathrm{~mol} \%$.

The type strain is LMG $18435^{\mathrm{T}}\left(=\mathrm{CIP} 107762^{\mathrm{T}}=\mathrm{Logan}\right.$ collection number $\mathrm{B} 1724^{\mathrm{T}}=$ isolate $\left.\mathrm{SSI} 024^{\mathrm{T}}\right)$.

\section{Acknowledgements}

We are very grateful to P. Convey of the British Antarctic Survey for collecting soil samples from Candlemas Island. We are most grateful to bioMérieux sa and bioMérieux, Inc. for providing API materials and for supporting G.F. and M.R.-D.; P.D.V. is indebted to the National Fund for Scientific Research, Flanders (FWO, Vlaanderen) for personnel and research grant G.0156.02.

\section{References}

Holdgate, M. W. \& Baker, P. E. (1979). The South Sandwich Islands: I. General description. Br Antarct Surv Sci Rep 91, 1-76.

Logan, N. A. \& Berkeley, R. C. W. (1984). Identification of Bacillus strains using the API system. J Gen Microbiol 130, 1871-1882.

Logan, N. A., Lebbe, L., Hoste, B., Goris, J., Forsyth, G., Heyndrickx, M. \& De Vos, P. (2000). Aerobic endospore-forming bacteria from geothermal environments in northern Victoria Land, Antarctica, and Candlemas Island, South Sandwich archipelago, with 
the proposal of Bacillus fumarioli sp. nov. Int J Syst Evol Microbiol 50, 1741-1753.

Logan, N. A., Lebbe, L., Verhelst, A., Goris, J., Forsyth, G., Rodriguez-Diaz, M., Heyndrickx, M. \& De Vos, P. (2002). Bacillus luciferensis sp. nov., from volcanic soil on Candlemas Island, South Sandwich archipelago. Int J Syst Evol Microbiol 52, 1985-1989.
Mesbah, M., Premachandran, U. \& Whitman, W. B. (1989). Precise measurement of the $\mathrm{G}+\mathrm{C}$ content of deoxyribonucleic acid by high-performance liquid chromatography. Int J Syst Bacteriol 39, 159-167.

Tomblin, J. F. (1979). The South Sandwich Islands: II. The geology of Candlemas Island. Br Antarct Surv Sci Rep 92, 1-33. 